\title{
Schenker's Fließender Gesang and the Concept of Melodic Fluency
}

Nicolas Meeùs

(University Paris-Sorbonne) 
The concept of melodic fluency is considered today an important one in Schenkerian theory. William Pastille (1990:71-72) shows that this notion, first presented in the first volume of Counterpoint, initiated the development of the Ursatz concept. The knowledge of the principle of melodic fluency, he adds, affords two abilities: "the ability to uncover long-range melodic motions and the ability to reveal underlying contrapuntal patterns", which "became the mainstays of his analytical approach." Allen Cadwallader and William Pastille (1992:120) confirm that Schenker "formally introduced" the concept of melodic fluency in Counterpoint I, and define it as "essentially a name for good voice leading in strict counterpoint". William Rothstein, who defines Schenker's concept of melodic fluency as a "stepwise continuity in the upper voice" (1991:292), makes it an essential element of his description of "implied tones", when a conjunct tone is implied in an apparently leaping melodic line.

Whether Schenker really developed a concept of melodic fluency will be further discussed below. It must be stressed from the start, however, that the transformation of the qualifying fließend (in fließender Gesang) into the substantive "fluency" (in "melodic fluency") probably was instrumental in transforming the mere idea of a flowing melody into a fully formed concept. This concept, in addition, soon gained qualifications that did not exist in Schenker. Thomas Pankhurst (2008:18-19) says that it "describes the way in which Palestrina's polyphony tends to keep different types of melodic motion in balance and proportion", introducing the name of Palestrina for the first time in this context. Nicholas Cook (2007:26) writes that Schenker had borrowed the term "melodic fluency" from Fux, but this only is the result of a somewhat debatable formulation in the English translation of Kontrapunkt. ${ }^{1}$

The concept even entered neo-Riemannian theory: Richard Cohn (1998:174-75) considers it characteristic of 19th-century harmonic theory, as opposed to an 18th-century one more dependent on root relations. He traces "melodic fluency" among others to Adolf Bernhard Marx's Die Lehre von der Musikalischen Komposition (1841), whose presentation of it "essentially amounts to Schoenberg's 'principle of least motion'." 2 The concept, as we will see, nevertheless is essentially an 18th-century one.

Even if Schenker apparently did not make use of the term fließender Gesang before Kontrapunkt I, ${ }^{3}$ the idea did appear before, in Harmonielehre, under a slightly different

\footnotetext{
$1 \quad$ Cook refers to Schenker (1987:302) quoting Fux about the need to avoid monotony in syncopes. Fux (1725:74) had written ... quia \& canendi rationi, \& progressûs concinnitati haud parùm concedendum est, which Schenker (1910:391) had translated as Denn man muß auf den Gesang und die Fortschreitungen nicht wenig sehen. Rothgeb and Thym (Schenker 1987:302) produce a somewhat excessive interpretation when they translate "... one must pay careful attention to matters of melodic fluency and continuity" (my italics). Rothgeb and Thym therefore appear responsible for the creation of the expression "melodic fluency". See also note 9 below.

$2 \quad$ The "principle of least motion" (Gesetz des nächsten Weges) appears to originate in Dürrnberger 1841:53. It apparently was handled down to Schoenberg (and Schenker) through Bruckner: see Wason 1985:70. There are precedents, e.g. in Rameau (1722:186-7): On ne peut passer d'une Notte à une autre que par celle qui en est la plus voisine ("One cannot pass from one note to another but by that which is the most neighboring"). 3 William Pastille (1990:83) noted that Schenker's analysis of J. S. Bach's Chromatic Fantasy and Fugue, of 1909, already made some use of the concept, albeit without discussing it.
} 
formulation. He describes there the fact that, in counterpoint, the voice leading does not depend on scale steps: "rather, one has to direct the ear, without regard for the meaning of the individual chords, to the fact that two, three or four voices move from chord to chord; and this will be pursued above all by a beautifully flowing motion of the voices (einen schönen fließenden Gang der Stimmen) and by the principle of the most natural solution of the most naturally conceived situations" (Schenker 1906:198-199) ${ }^{4}$. In Kontrapunkt I, Schenker (1910:104) quotes Cherubini's rule 6 of note against note counterpoint, where he apparently finds the origin of fließender Gesang:

Cherubini lehrt in der 6. Regel (S. 7): „Alle Fortschreitungen sollen diatonisch oder natürlich sein, namentlich was die Melodie anlangt, und der fließende Gesang ist im strengen Stile immer besser als der sprungweise.

This German translation of Cherubini's French comes from the bilingual edition published by Kistner in Leipzig and Schlesinger in Paris, probably around or in 1835, with a translation by Franz Stoepel ${ }^{5}$. Rothgeb and Thym (Schenker 1987:74) return to Cherubini's French text and translate:

Cherubini teaches in rule VI (p. 7): All movement should be diatonic or natural, in the melodic domain in particular; and conjunct motion better suits strict counterpoint than disjunct motion. ${ }^{6}$

It appears therefore that, contrarily to what Schenker may have thought, the concept does not really originate in Cherubini.

Schenker (1910:133-40/1987:94-100) devotes a full paragraph to "The requirement of flowing melody", recalling Cherubini's opinion that "the motion is melodic and fluent when it progresses stepwise. It is leapwise when it progresses by intervals" (Schenker 1910:139/1987:99). ${ }^{7}$ I will come back on this paragraph in a moment, but we should first wonder why Stoepel transforms Cherubini's mouvement conjoint in fließender Gesang,

\footnotetext{
4 Schenker 1954:154, translation slightly modified. Later (1906:214/1954:168), Schenker also comments on Hassler's ability to satisfy the requirements of voice leading by fluid progressions (fließende Gang) of all voices.

5 Schenker 1910:4 specifically mentions this edition. That he refers to it is confirmed by the mention of "p. 7" in the quotation above. See also note 8 below.

$6 . \quad .7$ " in the quotation above. See also note 8 below.

Cherubini's French text reads: Tous les mouvements doivent être Diatoniques ou Naturels, pour ce qui concerne la mélodie ; et le mouvement conjoint convient mieux au style du contre-point rigoureux que le mouvement disjoint. (Cherubini [c1835]:7) In Kontrapunkt II, Schenker once again quotes Cherubini (c1835:35): Dans ce mélange des deux espèces, il est presque impossible que l'une des deux parties ne soit presque continuellement disjointe. II faut donc remonter à la rigueur de la règle, qui prescrit d'employer le mouvement conjoint de préférence à l'autre. Rothgeb and Thym follow here the German of Stoepel, as quoted by Schenker: "In the combination of the two species, it is almost impossible to prevent one of the voices from moving in leaps. One must therefore sacrifice the rule that prescribes a preference for melodic fluency." (Schenker 1922:193/1987:197).

7 This once again comes from Stoepel's German translation, Die Bewegung istmelodisch und fliessend, wenn sie stufenweise fortschreitet. Sie ist springend, wenn sie durch Intervalle fortschreitet, which does not really translate Cherubini's French: Mélodiquement, on appelle mouvement conjoint une succession de sons procédant graduellement. On dit mouvement disjoint quand les sons se succèdent par intervalles. (Cherubini [c1835] :2)
} 
which does not really mean the same. ${ }^{8}$ The answer undoubtedly is that the idea of flowing melody, of fließender Gesang, had been a constant concern of German counterpoint theory since at least a century before Cherubini. ${ }^{9}$ Johann Mattheson (1739:140), for instance, describes four qualities of a good melody: it should be light, clear, flowing and lively (leicht, deutlich, fliessend und lieblich). He also asks this question which must have struck Schenker: "What is more flowing than repetition?" (Was ist fliessender, als die Wiederholung?, 1739:23). But the idea of flowing (fließen) is so common that it could be found almost everywhere, in different contexts.

Kirnberger (1776) devotes a full section to "The melodic progression and the fluent melody". ${ }^{10}$ He writes that melodies should be lightly flowing (leicht fließend), unless for very particular reasons. He describes requirements of flowing melodies: they should express the tonality by beginning on the tonic, the mediant or the dominant; dissonant melodic intervals (tritone or major seventh) should be avoided, or at least resolved. He stresses that seconds and thirds make the melody more flowing than leaps of a sixth, a seventh or an octave, even although these may enhance it. After a lengthy discussion of the melodic use of the various intervals, Kirnberger turns to the differences between fluent melodies for high or low voices: a fluent bass may include more leaps than a discant one; instrumental fluent melodies may include arpeggios and other leaps than could not be accepted in vocal ones.

Although the term fliessend (flowing) forms an integral part of Schenker's vocabulary, the expression fliessender Gesang can be found nowhere else in his published writings than in the two volumes of Kontrapunkt. ${ }^{11}$ Not unlike Kirnberger, Schenker devotes a full section of Kontrapunkt I to "The requirement of melodic fluency", 12 but he obviously is conscious of the previous existence of the idea and of its name, for instance when he speaks of the "so-called flowing melody" (1910:116),13 or when he writes: "This

$8 \quad$ There is another German translation of Cherubini, by Gustav Jensen, 1896, mentioned in the Hinterberger list of Schenker's library. Cherubini's text quoted in note 7 above becomes Man nennt die Bewegung melodisch und fliessend, wenn sie stufenweise fortschreitet, springend, wenn die Intervalle grösser sind. The rule quoted in note 6 reads: Alle Fortschreitungen sollen diatonisch sein, was die Melodie anbelangt; ferner entspricht die stufenweise Bewegung besser dem Charakter des strengen Satzes, als die sprungweise.

9 One of the earliest occurrences is in Scheibe's Critischer Musikus, when he characterizes the Italian style as having "at all time a widely prolonged, but flowing melody (fließender Gesang), which calls for a rather light and moderate accompaniment" (1738:117), or when he comments choir writing in poetic oratorios (1738:170-71). The idea might come from that of flexibili motus in Fux's definition of florid counterpoint: Species ista Contrapunctum floridum appellatur, sic dictum, quia omnis generis ornatu, canendi gratiâ, flexibili motuum facilitate, concinnâ figurarum varietate, ùt hortus flosculis florere debet (1725:76). Schenker (1910:400-401) translates as Diese Gattung heisset der verblumte Contrapunct (contrapunctum floridum), weil in solchen allerley Zierrathen, fließende Bewegungen, und verschiedene Veränderungen, des Gesangs wegen, wie in einem Blumengarten vorhanden seyn müssen. See Schenker 1984:310.

10 Dritter Abschnitt. Von der melodischen Fortschreitung und dem fließenden Gesange, 1776:77-104.

11 The expression actually occurs once in Der freie Satz, but Schenker puts it there in the mouth of Haydn, who would have said: "... ein Tonstück soll haben einen fließenden Gesang, zusammenhängende Ideen ..." (1935:208). Oster translates this as "... a composition should have a songful flow, coherent ideas ..." (1979:128). 
line is called the 'flowing melody'" (1910:134), putting the term within quotation marks. ${ }^{14}$ It may therefore have been somewhat presumptuous to view "melodic fluency" as a novel Schenkerian concept. Schenker, on the contrary, may have conceived it as belonging to a venerable tradition in which he was keen to inscribe his own theory.

On the other hand, William Pastille and his followers are right to stress the particular importance of the idea of melodic fluency in shaping some of the most important traits of Schenkerian theory, especially in its period of formation in the 1910's. Melodic fluency may be linked with the origins of the concept of Urlinie, as Pastille claims (1990:74), but the situation is not as clear as he writes. In the Erläuterungsausgabe of Beethoven's op. 101 (1920), where Schenker uses the term Urlinie for the first time, there is a puzzling reference to Kontrapunkt I. He writes:

\begin{abstract}
It is because of the slowing down of the publication of my works that, despite so many occasions offered, I have omitted until now to speak of the concept of Urlinie, of which the last shaping and the last explanation belong to band II3 of my "New Musical Theories and Fantasies". Because in the meanwhile the printing progresses and a prospect exists that the volume may be produced is foreseeable time, I will now for the first time in the frame of the Erläuterungsausgaben speak of this concept, and somewhat more elaborately than I have been able to do in III, where I mentioned it for the first time on p. 136. $(1920: 22)^{15}$
\end{abstract}

The problem is that p. 136 of Kontrapunkt I contains only the last lines of text and the last musical example of the discussion of fließender Gesang, and is devoted for the most part to a criticism of Bruckner's lack of fluent melodic writing: the reference seems somehow wrong ${ }^{16}$. And the allegedly more elaborate description of the concept of Urlinie that Schenker announces for the commentary to op. 101 certainly is less detailed than that of fließender Gesang in Kontrapunkt I.

Schenker stresses that "the Urlinie is possession of the genius alone, and that explains why its knowledge did not long ago take it down from its elevation." This does not seem really compatible with the idea that fließender Gesang was a well-known, about two century old notion. In the same page of the Erläuterungsausgabe of op. 101, Schenker adds:

\begin{abstract}
While considering the Urlinien, one should not let oneself be disillusioned by the fact that they resemble any other in continuous lines of seconds, in repetitions, or also in an ascending and descending regularity, similar to an inspiration-expiration. It is the affair of the artist to elicit the ascending and the descending, and together the primal laws of voice leading and of the degrees, in ever new plays of proper motives and melodies, through this determined number of second progressions, through this art of repetitions, through the production of these particular ascending and descending tensions, and so doing to attain in each case the individual: semper idem sed non eodem modo. (Schenker 1920:22)
\end{abstract}

\footnotetext{
14 Man nennt diese Linie den „fließenden Gesang.. Cf. Schenker 1987:94.

15 II3 refers to Der freie Satz, which Schenker still hoped to publish as vol. III of Kontrapunkt, itself tome II of the New Musical Theories and Fantasies, while Il1 refers to vol. I of the same.

16 Hedi Siegel (1999:19 note 25) notes that Schenker, in the 1917 manuscript version of vol. II3, makes the same reference to Kontrapunkt I, leaving a blank for the page reference. She adds: "the context makes it clear that Schenker is referring to Kontrapunkt I, p. 136." But this blank left for the page number may as well indicate that there was a problem with the reference itself.
} 
This description of the techniques of producing an Urlinie - continuous lines of seconds, repetitions, and regularity in ascending and descending - do resemble his earlier descriptions of a fließender Gesang, and it would seem that what belongs to the genius alone is the capacity to make each of them different and individual.

As mentioned above, Schenker recalls Cherubini's opinion (in Stoepel's translation) that "the motion is melodic and fluent when it progresses stepwise" Schenker himself does not endorse such a restrictive definition, however. He writes:

In this definition, melodic fluency is, without doubt, conceived too narrowly. It certainly tolerates leaps too, so long as they are integrated in the whole in such a way that they do not disturb the equilibrium. Nevertheless, an irrefutable truth is contained in Cherubini's little remark, namely that it is precisely the second which is the best foundation for "melodic fluency." (Schenker 1910:139/1987:99)17

William Pastille apparently takes this and similar statements to mean that "the principles of melodic fluency need not be slavishly maintained on the music's surface, may angularities and disjunctions may appear at the surface level if one or more guiding lines beneath the surface exhibit melodic fluency." (1990:72) Melodic fluency, in other words, would belong to the middleground and the background (and above all, of course, to the Urlinie itself), and may justify a superficial lack of fluency in the foreground. The search for an underlying melodic fluency would have become an essential part of Schenker's analytic technique, leading to the concepts of Urlinie and Ursatz.

This is not always true, however. Pastille comments Schenker citation of the opening theme (bars 1-18) from the Adagio of Beethoven's Ninth Symphony as an example of melodic fluency, because leaps "are recovered by means of a second, a change in direction, or both." But this is not exactly what Schenker says. Rather, Schenker quotes bars $43 \mathrm{ff}$. and $99 \mathrm{ff}$. of the Adagio as illustrations of flowing melodies in free composition. These, he writes "may strive to simply decorate a given melodic line in the sense of an explicit (ausgesprochener) monody - one may think for instance at the so genially set violin figures in the Adagio of Beethoven's Ninth symphony (bars $43 \mathrm{f}$. or $99 \mathrm{f}$.), which are only a variation of the simple line of the theme" (1910:135) ${ }^{18}$. Immediately before this, Schenker had mentioned composite melodies, which "express several latent voices in a unified fashion." What he may mean here is that the variations make such a melody more flowing by expressing it more explicitly as a monody, while at first it was more polyphonic and, as such, not quite fluent.

Figure 1 below illustrates this. The first line is the beginning of the theme (bars 3-6), which may be considered a composite melody, unfolding fragments that may be considered to belong to separate voices. The second line shows the variation of bars 43-46 and the third the variation of bars 99-102. Each of these variations fill in the leaps of the theme. This is particularly manifest in the third bar of the example, where the arpeggio

17 So ausgedrückt ist der fließende Gesang ohne Zweifel zu eng verstanden. Verträgt er sicher doch auch Sprünge, sofern sie nur derart ins Ganze sich fügen, daß sie das Gleichgewicht nicht stören. Freilich, eine unwiderlegliche Wahrheit steckt gleichwohl in jener kleinen Bemerkung Cherubinis, nämlich die, daß just die Sekund am besten das "Fließende”, das "Melodische” des Gesanges begründet. 
$d-f-b b-d$ of the theme is transformed, both in bar 45 and in bar 101, in an octave line ascending from $d$ to $d$; other leaps in the theme similarly are filled in and made more flowing by the diminutions.

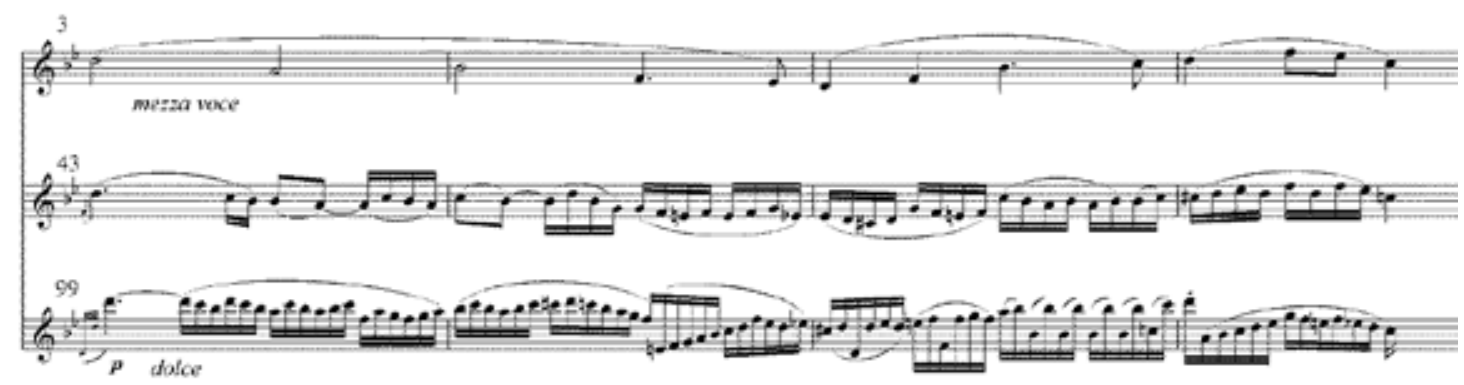

Figure 1: Beethoven, Ninth Symphony, Adagio. Bars 3-6, 43-46 and 99-102

This is a case where fluency is gained by a surface elaboration. Schenker gives no indication whether the theme itself could be shown to possess an underlying fluency.

Other cases, on the contrary, do show that a more fluent voice leading may be underlying a more disjunct melody. A case often cited is that of the Prelude of J. S. Bach's English suite in D minor. Figure 2a gives Bach's text and Figure 2b shows how Schenker extracts the top voice op the polyphonic web and reduces it to a fluent melody, "the most concealed result, the ultimate product of ascending and descending figurations" (Schenker 1910:135-36/1987:96).
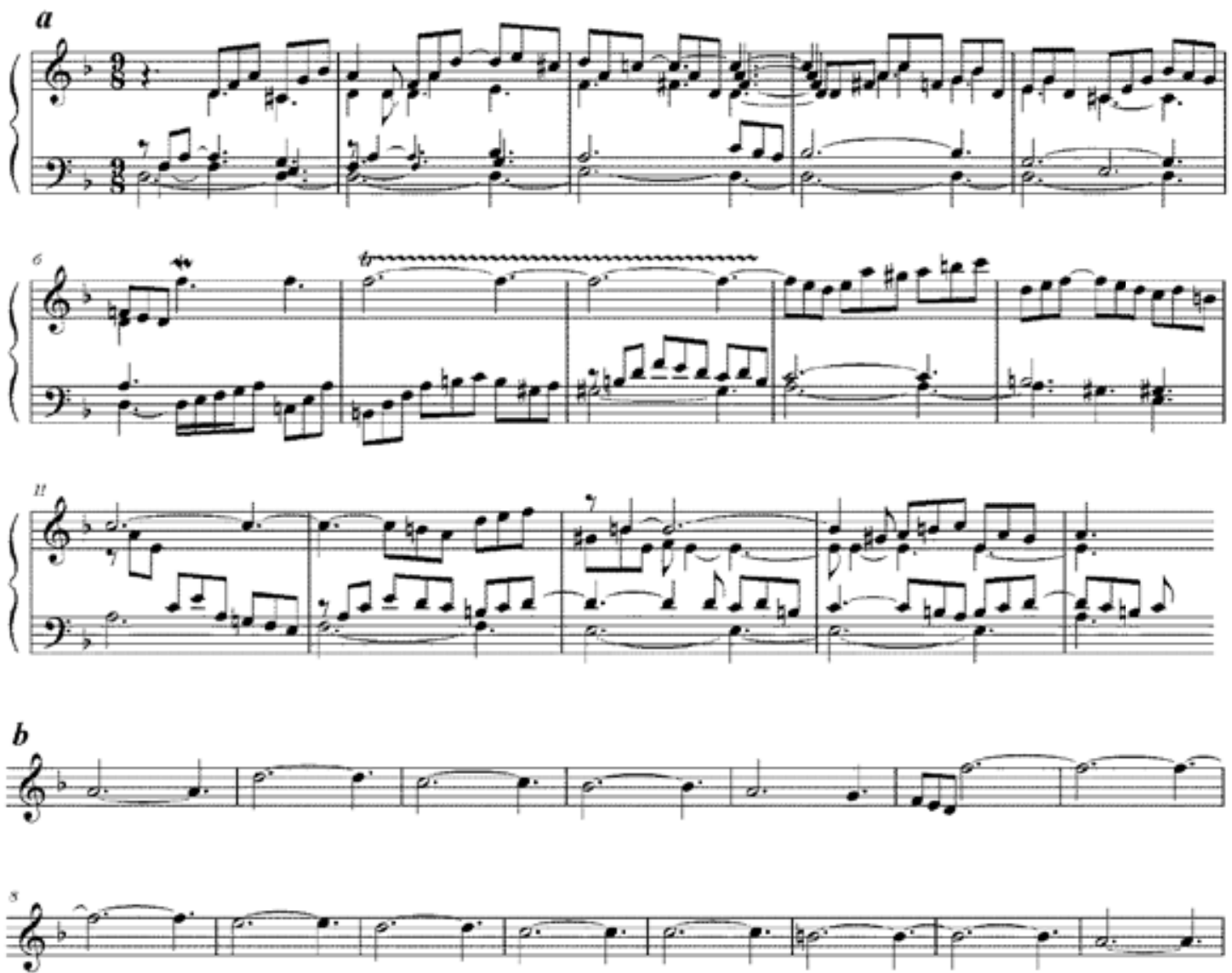

Figure 2: a) J. S. Bach, English suite in D minor, Prelude; b) reduction of the melody (Shenker 1910:136/1987:96) 
The link between fließender Gesang and Urlinie appears to be found in the Erläuterungsausgabe of Beethoven's op. 101. We have seen above how Schenker apparently refers there to the discussion of the concept in Kontrapunkt I. As William Pastille rightly noted (1990:76), the analysis of the theme of the second movement "reveals that Schenker has recorded melodically fluent versions of the several lines making up the setting [...], resulting in the predominant movement by seconds that is characteristic of melodic fluency." Figure 3 shows first the theme itself, then the two successive reductions proposed by Schenker, the first labelled Ausführung and the second Urlinie (Schenker presents them in reverse order). The arpeggios in the right hand are broken down to reveal several linear progressions that indeed correspond to the definition of fluent melodies.
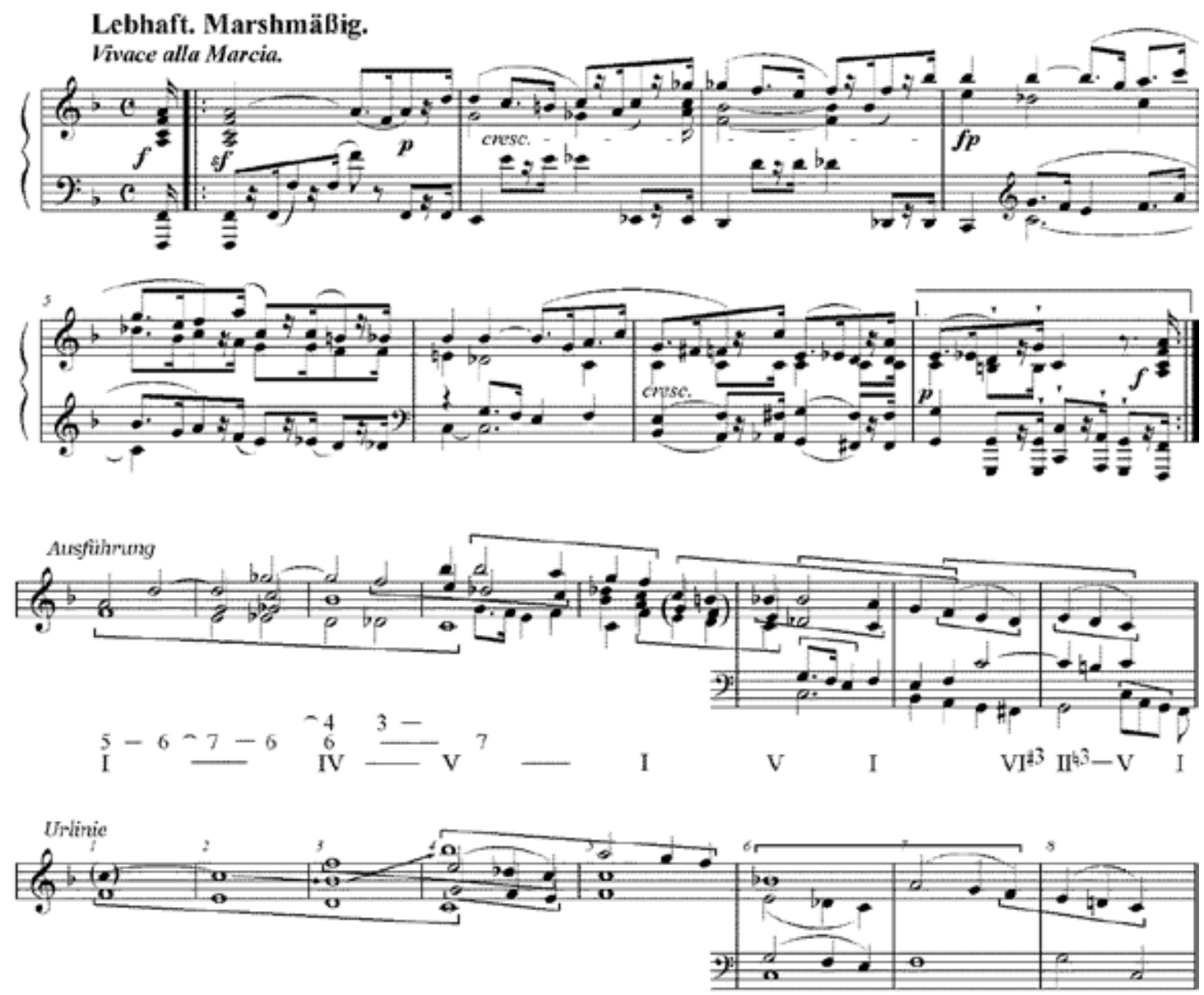

Figure 3: Beethoven, op. 101 II, bars 1-8, and two reductions by Schenker (1920:36)

The problem, however, is that Schenker in the Erläuterungsausgabe of op. 101 nowhere explicitly refers to the idea of fließender Gesang, neither in this analysis of the second movement, nor in the general introduction, in the short discussion of the concept of Urlinie during which he makes the unclear reference to "p. 136" of Kontrapunkt 
I. There can be no doubt that the idea of fließender Gesang has been instrumental in shaping the concept of Urlinie, but the fact remains that Schenker never clearly links the two together ${ }^{19}$. The term is still used in Kontrapunkt II (1922/1987), mainly to describe the voice leading in counterpoint, but does not reappear in any of Schenker's published writings after that.

What makes the whole situation even more puzzling is that Schenker, in his plans of 1917 for Kontrapunkt $\mathrm{II}^{3}$ which was later to become Der freie Satz, had foreseen to include a discussion of fließender Gesang as governing the outer voices. Hedi Siegel believes that Schenker even takes the idea a step further, when he writes: "Of course one must imagine away all the unessential traits of both bass and soprano if one wishes to gain the impression of a principal line" (Siegel 1999:19-20). But one could read this differently and, when Schenker says that in order to gain the impression of a principal line one has to imagine away "unessential traits" that nevertheless must belong to fließender Gesang, one may understand that he is actually opposing the two. It may seem then that the reason of the abandonment of the idea of fließender Gesang in Schenker's writings has to do with his decision not to publish Der freie Satz as the third volume of Kontrapunkt. He must have realized that free composition was not merely a further case of contrapuntal writing, as Albrechtsberger for instance had described it (1790). ${ }^{20}$ He must have become aware, by the early 1920s, that his theories were taking a novel turn, that the requirements of an Urlinie were more strict that those of mere contrapuntal fluency or of free counterpoint, and that the two-century old idea of fließender Gesang could not do justice to the theories of free composition that he was developing.

There is no Schenkerian concept of "melodic fluency". There merely is an ancient idea of fluent melody that pervades the German theory of counterpoint and that was a source of inspiration for Schenker. But Schenker realized that his theory departed from ordinary German counterpoint theory, and that the traditional idea of fluent melody was insufficient to describe the requirements of his fundamental line. This is why he eventually conceived Der freie Satz as an independent work, and why he abandoned the idea of fließender Gesang.

\section{References}

ALBRECHTSBERGER, Johann Georg (1790). Anweisung zur Komposition. Leipzig, Breitkopf.

CADWALLADER, Allen, and William PASTILLE (1992). "Schenker's High-Level Motives". Journal of Music Theory 36/1, pp. 119-148.

\footnotetext{
19 Contrarily to Robert Morgan's claim (2014:89-91, particularly note 33), the terms are never clearly mentioned in connection with each other in any of Schenker's published works. The single possible link is the reference to p. 136 of Kontrapunkt I, but we have seen that it is all but clear.

20 Albrechtsberger (1790:17-19) devotes his Chapter 6 to the question of strict vs free writing

(6. Kapitel. Vom strengen und freyen Satze überhaupt). Free writing, for him, is basically instrumental counterpoint, without the constraints of vocal species counterpoint.
} 
CHERUBINI, Luigi [c1835]. Cours de contre-point et de fugue / Theorie des Contrapunktes und der Fuge, aus dem Fransösischen übersetzt von Dr. Franz Stoepel. Leipzig, Kistner, Paris, Schlesinger. New translation by Gustav Jensen, Cologne and Leipzig, Vom Ende's Vlg, 1896.

COHN, Richard (1998). "Introduction to Neo-Riemannian Theory: A Survey and a Historical Perspective". Journal of Music Theory 42/2 (1998), pp. 167-180.

COOK, Nicholas (2007). The Schenker Project. Culture, Race, and Music Theory in Fin-de-siècle Vienna. Oxford, Oxford University Press.

DÜRRNBERGER, Johann August (1841). Elementar-Lehrbuch der Harmonie- und Generalbass-Lehre. Linz, Normal Hauptschule.

FUX, Johann Joseph (1725). Gradus ad Parnassum. Vienna, Joannes Petrus Van Ghelen.

[HINTERBERGER, Heinrich (n.d.)]. Katalog XI. Musik und Theater. Enthaltend die Bibliothek des Herrn + Dr. Heinrich Schenker, Wien.

KIRNBERGER, Johann Philipp (1776). Die Kunst des reinen Satzes in der Musik, vol. II. Berlin, Königsberg, Decker.

MATTHESON, Johann (1739). Der vollkommene Capellmeister. Hamburg, Christian Herold.

MORGAN, Robert (2014). Becoming Heinrich Schenker. Music Theory and Ideology. Cambridge University Press.

PANKHURST, Thomas (2008). Schenker Guide. A Brief Handbook and Website for Schenkerian Analysis. New York, London, Routledge.

PASTILLE, William (1990). "The Development of the Ursatz in Schenker's Published Works". Trends in Schenkerian Research, Allen Cadwallader ed., New York, Schirmer, pp. 71-85a.

RAMEAU, Jean-Philippe (1722). Traité de L'Harmonie Reduite à ses Principes naturels. Paris, Ballard.

ROTHSTEIN, William (1991). “On Implied Tones”. Music Analysis 10/3, pp. 289-328.

SCHEIBE Johann Adolph (1738). Critischer Musikus, vol. I. Hamburg, von Wierings Erben.

SCHENKER, Heinrich (1906/1954). Harmonielehre. Stuttgart and Berlin, Cotta, 1906. 
Harmony, partial transl. by Elisabeth Mann Borgese, edited and annotated by Oswald Jonas. Chicago, The University of Chicago Press, 1954.

----- (1910/1987). Kontrapunkt I, Cantus firmus und zweistimmiger Satz. Vienna, Universal, 1910. Counterpoint I, translated by John Rothgeb and Jurgen Thym. New York, Schirmer, 1987.

----- (1920). Beethoven-Schenker. Erläuterungs-Ausgabe der letzten fünf Sonaten. Sonate A Dur op. 101. Wien, Universal.

----- (1922/1987). Kontrapunkt II, Drei- und merhstimmiger Satz. Übergänge zum freien Satz. Vienna, Universal, 1922. Counterpoint II, translated by John Rothgeb and Jurgen Thym. New York, Schirmer, 1987.

SIEGEL, Hedi (1999). "When 'Freier Satz' was part of Kontrapunkt: a preliminary report”. Schenker Studies 2, Carl Schachter and Hedi Siegel ed., Cambridge University Press, pp. 12-25.

SULZER, Johann Georg (1771). Allgemeine Theorie der Schönen Künste. Leipzig, Weidemanns Erbe.

WASON, Robert W. (1985). Viennese Harmonic Theory from Albrechtsberger to Schenker and Schoenberg. Ann Arbor and London, UMI Research Press. 